\title{
Predation on amphibians by spiders (Arachnida, Araneae) in the Neotropical region
}

\author{
Marcelo Menin ${ }^{1}$, Domingos de Jesus Rodrigues ${ }^{1}$ and Clarissa Salette de Azevedo ${ }^{2}$ \\ 1 Coordenação de Pesquisas em Ecologia, Instituto Nacional de Pesquisas da Amazônia, Av. André Araujo \\ 2936, 69011-970, Manaus, AM, Brazil. E-mail: menin@inpa.gov.br. \\ 2 Coordenação de Pesquisas em Entomologia, Instituto Nacional de Pesquisas da Amazônia.
}

\begin{abstract}
Predation on amphibians by spiders (Arachnida, Araneae) in the Neotropical region. Herein, we report observations about spider predation on anurans (adults and juveniles) in Central Amazonia and a literature review of spiders preying on amphibians in the Neotropical zoogeographic realm. We conducted field observations in Reserva Florestal Adolpho Ducke, Manaus, AM, and observed eight predation events on Bufonidae, Dendrobatidae, Hylidae, and Leptodactylidae frogs. The predators belong to the spider families Ctenidae, Pisauridae and Theraphosidae. Besides the families of spiders found in this study, two others - Lycosidae and Sparissidae - were found in literature. Frogs from families Centrolenidae and Microhylidae, and a caecilian (Gymnophiona, Caeciliidae) were found in literature also. There is a significant correlation between the length of the anuran (snout-vent length) and the length of spiders (cephalotorax and abdomen length). The size of the spider is similar or slightly lesser than the anuran prey. In general, the spiders preyed on adult and juvenile frogs in the breeding season. Spiders are opportunistic predators and prey on small frogs. Theraphosidae prey upon sub adults of large anurans and caecilians. As spiders can reach high densities on the forest floor - especially species of the genera Ctenus and Ancylometes - this interaction may be ecologically important for breeding anurans. Our reports and literature data provide evidence that spiders commonly prey on amphibians in Neotropic, but the impact of predation on populations of amphibians is unknown.
\end{abstract}

Keywords: Anura, Gymnophiona, predator-prey interaction, Amazonian, Neotropical region, intraguild predation.

\section{Introduction}

Small vertebrates such as gekkonid lizards (see Bauer 1990 for review) and amphibians (Duellman and Trueb 1994, Rubbo et al. 2003)

Received 27 August 2004.

Accepted 24 March 2005.

Distributed October 2005. are prey for a great variety of vertebrate and arthropod predators, and it is apparent that some arthropods may cause significant mortality among some vertebrate populations (review in McCormick and Polis 1982). According to McCormik and Polis (1982), representatives of four classes of Arthropoda are predators of vertebrates: Arachnida, Insecta, Crustacea, and Chilopoda. Despite the fact that the reports of 
attacks by arthropods on small vertebrates are numerous, it is difficult to assess the impact of arthropod predators on their vertebrate prey (McCormick and Polis 1982). Detailed studies have been made about predation by aquatic insects on larval amphibians (Heyer et al. 1975) and by insect larvae on non-aquatic eggs (Villa et al. 1982, Menin and Giaretta 2003).

Among small vertebrates, adult and juvenile amphibians are preyed upon by aquatic insects, such as water bugs (Hinshaw and Sullivan 1990, Toledo 2003, Giaretta and Menin 2004), and arachnids, such as scorpions (Villanueva-Rivera et al. 2000) and spiders (Goin 1943, Formanowicz et al. 1981), which are considered important predators of terrestrial frogs (Hayes 1983). Although most examples of spider attacks on amphibians are based on fortuitous observations of single events, spiders were observed preying upon and eating a great variety of frogs in different places around the world (Goin 1943, McCormick and Polis 1982, Mitchell 1990, Raven 1990, Owen and Johnson 1997, Blackburn et al. 2002). Besides this, the small leaf-litter dwelling species, such as most leptodactylids and dendrobatids, are well within the size range of prey of many spiders.

Herein, we report our own observations about events of predation by spiders on adult and juvenile frogs in Central Amazonia and undergo an extensive literature review of spiders preying on amphibians in the Neotropical zoogeographic realm.

\section{Material and Methods}

We conducted field observations in Reserva Florestal Adolpho Ducke - RFAD (02 ${ }^{\circ} 55^{\prime}-03^{\circ} 01^{\prime}$ S, 59 $\left.53^{\prime}-59^{\circ} 59^{\prime} \mathrm{W}\right)$, in the municipality of Manaus, state of Amazonas, Central Amazonia, northern Brazil, between January and May 2004 and in January 2005. Seven observations were made at night in a temporary pond (ca. $6 \times 6 \mathrm{~m}$ ) and along trails in terra-firme forest. All observations were occasional and realized during surveys of nocturnal anurans. Only one obser- vation was made in the afternoon in a trial. The measures of the body size represent the cephalotorax and abdomen length to spiders and snout-vent length (SVL) to frogs. Measures were made with vernier calipers to the nearest $0.01 \mathrm{~mm}$. The relation between the size of frogs and spider was analyzed by the Pearson Correlation test (r) (Zar 1999) using data from this study and cases in literature for which sizes of both predator and prey were available. The size data were log-transformed (base 10) prior to analysis. Spiders were preserved in $70 \%$ alcohol and deposited in the Invertebrate Collection of the Instituto Nacional de Pesquisas da Amazônia (INPA). Frogs were deposited in the INPA Herpetological Collection (INPA-H 11891, 11898, 11899).

We conducted an extensive literature review on spiders preying on amphibians (adults and juveniles, not larvae) in the Neotropical zoogeographic realm. In addition, we contacted other researchers that conducted works in Central Amazonia, which made their unpublished data available. We considered as 'predation' those events for which the capture of prey was reported or when the capture was not observed but the prey was still alive.

\section{Results}

\section{Observed Events}

Bufo marinus - on 16 April 2004 a theraphosid spider Theraphosa blondi (84.12 mm) was observed eating a juvenile $B$. marinus $(90.52$ $\mathrm{mm}$ ). The spider was standing over the toad with its chelicerae in the head of the frog. There was a hemorrhage around the bite, and another bite was observed in the gular region. The frog was still alive but motionless when the spider was captured. After two hours, the frog was still alive but the left eye and the right hind limb were paralyzed.

Dendrophryniscus minutus - on 12 January 2005 a male pisaurid spider Ancylometes rufus (ca. $30 \mathrm{~mm}$ ) was observed capturing a passing 
female D. minutus (ca. $22 \mathrm{~mm}$ ) on leaf-litter. After 15 minutes, the frog was still alive, but after its death, the right leg and part of the belly were deformed, probably due to the removal of liquefied internal tissues.

Colostethus stepheni - on 18 May 2004 a juvenile male ctenid spider Ctenus amphora (16.4 mm) was observed eating an adult female C. stepheni $(18.4 \mathrm{~mm})$ on a leaf from a shrub about $0.30 \mathrm{~m}$ above the ground (Figure 1A).

Dendropsophus minutus - on 6 March 2004 a juvenile male pisaurid spider Ancylometes rufus $(26.1 \mathrm{~mm})$ was observed eating an adult $D$. minutus (ca. $22 \mathrm{~mm}$ ) (Figure 1B). The spider was found perched on a leaf $0.50 \mathrm{~m}$ above the water surface of a temporary pond. The right side of the body, head and trunk of the frog had been eaten; the left hind and fore limbs were intact, but it was impossible to determine the sex of the frog. On 7 March 2004, in the same pond, a male A. rufus $(31.0 \mathrm{~mm})$ was observed about $0.05 \mathrm{~m}$ above water surface on a leaf preying on a gravid female $D$. minutus (24.5 mm). The spider was holding the hylid with its pedipalps and first pair of legs, and the chelicerae penetrated the side of the frog. The spider released the frog when disturbed. The frog was still alive, but floated motionless in the water.

Adenomera andreae - on 14 January 2004 a male $A$. rufus (ca. $30 \mathrm{~mm}$ ) was observed eating a female leptodactylid A. andreae (ca. $24 \mathrm{~mm}$ ) on the leaf-litter (Figure 1C). The spider held the hylid with its pedipalps and the chelicerae penetrated the head of the frog. The frog struggled briefly and was completely immobilized. On 15 March 2004 a juvenile ctenid spider Ctenus villasboasi $(18.5 \mathrm{~mm})$ was observed eating an adult male $A$. andreae (20.9 mm). The spider was perched on a shrub's leaf about 0.50 $\mathrm{m}$ above the ground, with its chelicerae in the head of the frog. At the time, the frog was still alive and completely immobilized. About one hour later, the frog was dead with the region of the head partially eaten. On 1 May 2004 a juvenile ctenid spider Ctenus sp. (8.0 mm) was observed capturing a juvenile A. andreae (11.5 $\mathrm{mm}$ ) on the leaf-litter at afternoon. The frog struggled briefly, but was completely immobilized after about 60 seconds.

\section{Literature Data}

We collated published data on 16 articles or notes. In the 16 articles or notes, 21 reports were found, in eight predation were observed and in ten feeding were observed. In three reports this information was not available.

A total of 15 species of frogs belonging to four families (Centrolenidae, Dendrobatidae, Hylidae, and Leptodactylidae) and one species of caecilian (Caeciliidae), were preyed upon by 13 species of spiders belonging to five families (Ctenidae, Pisauridae, Theraphosidae, Lycosidae and Sparassidae) (Table 1).

In general, the reports of spider attacks on amphibians are based on observations of single events; only one study showed experimental data and the impact of predations on a species of Eleutherodactylus (Formanowicz et al. 1981).

\section{Discussion}

The majority of reports found in the literature of predation on amphibians in the Neotropical realm were about anurans; only one report was found on a caecilian (Table 1), probably due to the fossorial habits of this taxon. Often the size of the predator and prey were not available in the original reference, and the actual evidence of predation (from capture to consume) was observed in few events. In much of them the authors observed the spiders eating their prey after the capture. There are some reports that spiders will scavenge dead insects (Cangialosi 1990, Sandidge 2003). However, a few spiders scavenge dead individuals encountered in the search for live prey, and these spiders are generally opportunistic feeders and not obligate scavengers (Wise 1993). In addition, the spiders are primarily predators and most of them remain motionless for a long time, sitting on the ground or on low plants waiting for their prey (Wise 

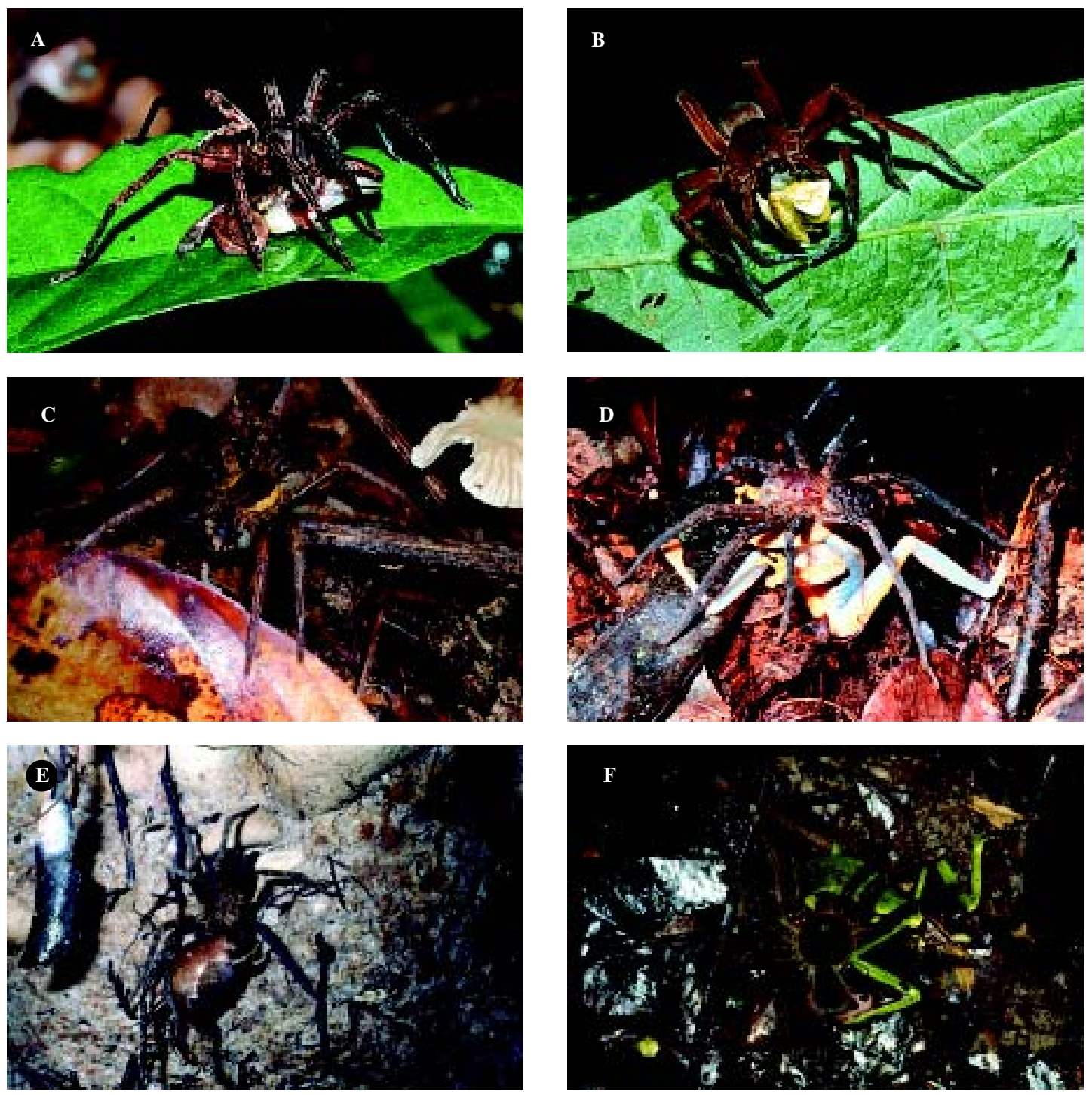

Figure 1 - Spider Ctenus amphora eating a female Colostethus stepheni (A); Ancylometes rufus eating an adult Dendropsophus minutus (B), Adenomera andreae (C) and Hypsiboas geographicus (D); Ancylometes sp. eating an adult Hamptophryne boliviana (E); theraposid spider eating an adult Phyllomedusa vaillanti (F). Photos: M. Menin (A and B), A. P. Lima (C), W. E. Magnusson (D) and W. Hödl (E and F).

1993, Höfer et al. 1994). Although most reports on attacks of amphibians by spiders in literature do not show the capture of the prey, our observations and those of other researchers indicate that predation is an important source of mortality for amphibians. Therefore, it is very probable that reports in literature where the capture of amphibians was not observed are actual events of predation.

The predaceous spiders that feed on 
Predation on amphibians by spiders (Arachnida, Araneae) in the Neotropical region

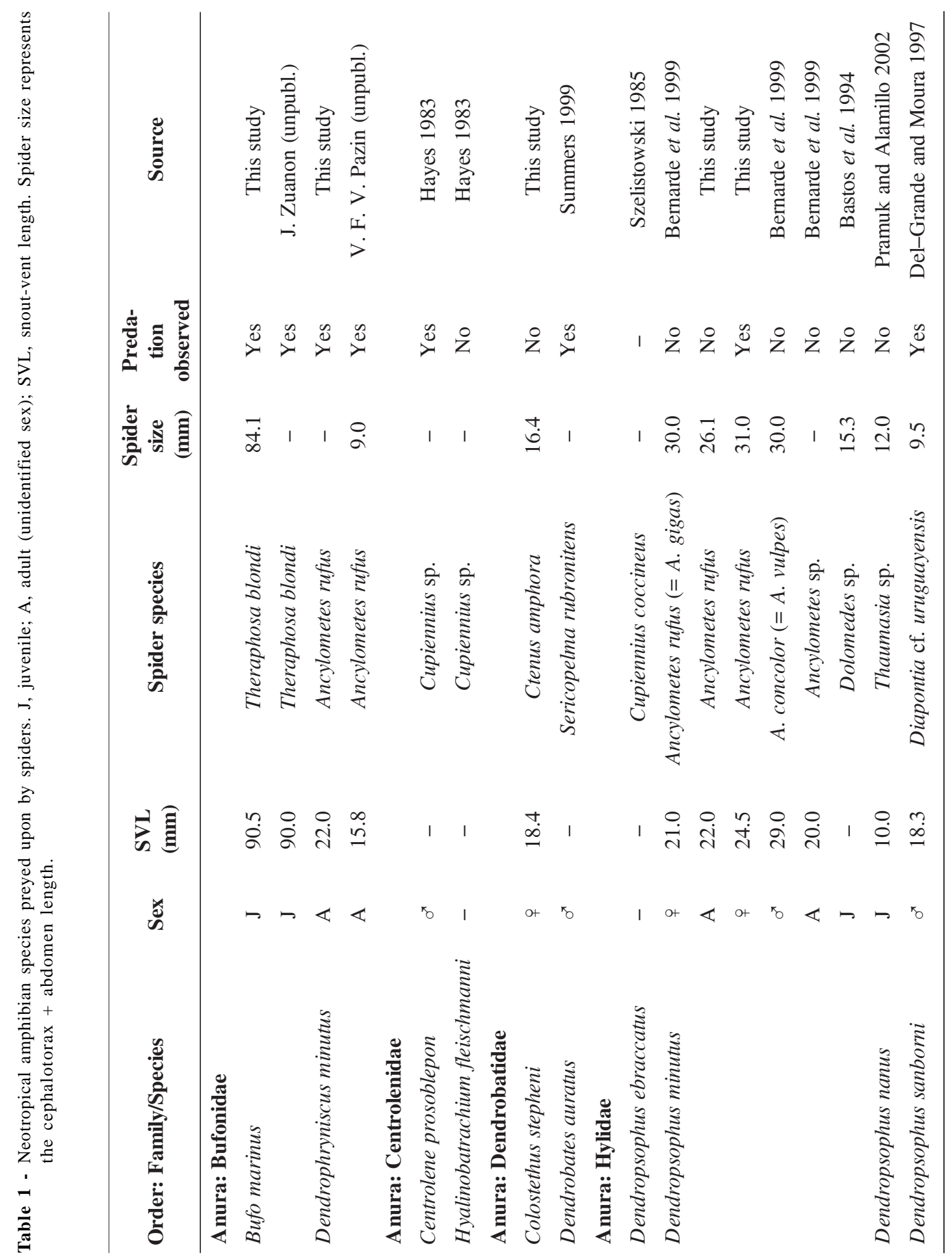

Phyllomedusa - 4(1), October 2005 
Menin et al.

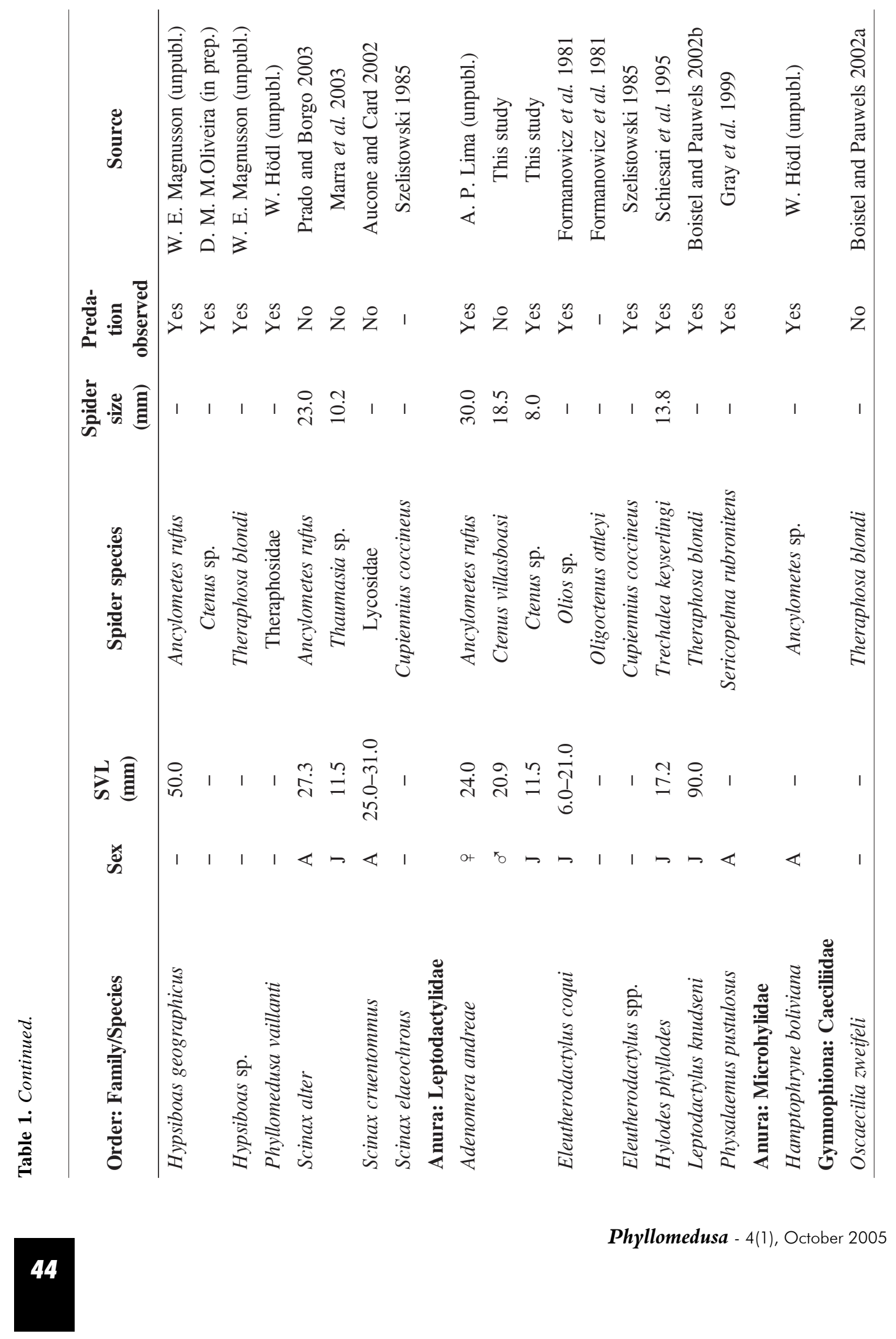


anurans in the Neotropical region include species from the families Pisauridae (genera Ancylometes, Dolomedes, Thaumasia, and Trechalea), Ctenidae (genera Ctenus, Cupiennius and Oligoctenus), Lycosidae (genus Diapontia), Sparassidae (genus Olios), and Theraphosidae (genera Theraphosa and Sericopelma). These spiders feed primarily on adults engaged in reproductive activity and juvenile frogs (Figure 1) (e.g. Del-Grande and Moura 1997, Pramuk and Alamillo 2002, this study). There is a significant correlation between anuran SVL and spider body size ( $\mathrm{r}=0.892 ; \mathrm{P}<0.001, \mathrm{~N}=15$ ) (Figure 2), specifically, the size of the spider is similar or slightly lesser than the anuran prey.

Spiders of the family Pisauridae are opportunistic predators that prey on small frogs, fishes and tadpoles (Bastos et al. 1994, Azevedo and Smith 2004). Members in the genera Ancylometes, Dolomedes, and Thaumasia were observed preying on small frogs (between 10 $30 \mathrm{~mm}$ SVL), which were mainly hylid frogs (Table 1). Dendropsophus minutus was the species with the highest number of reports. It is a common hylid frog that reproduces in temporary and permanent ponds (Lutz 1973), and the pisaurid spiders are commonly found near aquatic environments during the night (Höfer and Brescovit 2000, Azevedo and Smith 2004). The results of our study support the conclusion of Bernarde et al. (1999) that these spiders can be important predators of adults in breeding activity and metamorphosing $D$. minutus (Bastos et al. 1994).

The wandering spiders of the genus Ctenus are very similar in behavior and microhabitat use because they forage in and on the leaf-litter (Höfer et al. 1994, Gasnier and Höfer 2001). Diet of most species consists predominantly of invertebrates, but they occasionally prey on small lizards (Gasnier 1996) and frogs ( $C$. stepheni and $A$. andreae, this study).

Sub adults of large amphibians, such as the bufonid B. marinus (this study), the leptodactylid L. knudseni (Boistel and Pauwels 2002b) and caecilians (Boistel and Pauwels 2002a) are

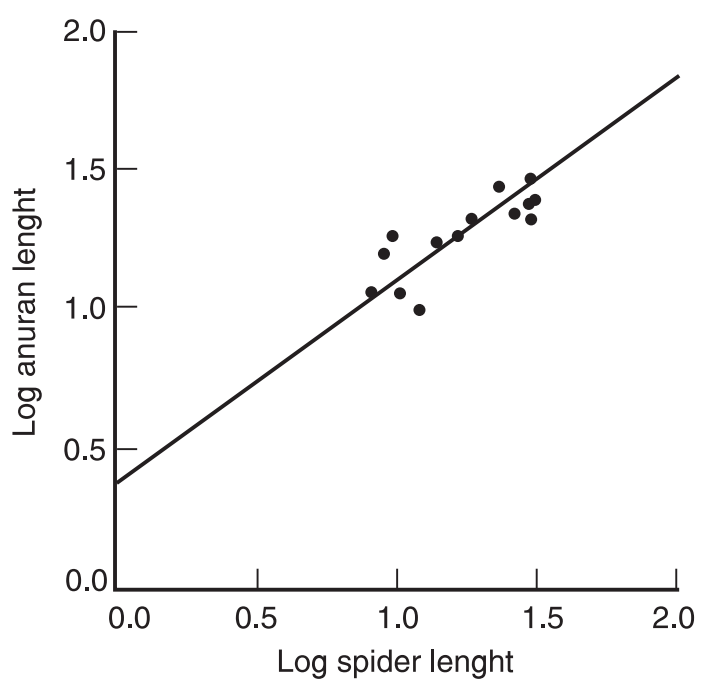

Figure 2 - The size relationship between spiders and anurans. Data from this study and cases for which both size of predator and prey were available are in Table 1.

preyed upon by large spiders. The giant tarantula Theraphosa blondi, and probably the tarantula Sericopelma rubronitens, eat a wide range of prey types. Theraphosa blondi is known to prey on skinks, snakes, mice (Azevedo and Smith 2004) and earthworms (Nyffeler et al. 2001) as well as frogs. Sericopelma rubronitens eats medium sized frogs (about 30-40 mm) (Gray et al. 1999, Summers 1999).

According to McCormick and Polis (1982), many vertebrates in the diet of arachnid predators are smaller than the predator. The presence of venoms, specialized trophic structures and the ability to make webs are foraging adaptations that allow many arthropod predators to capture similarly sized or even slightly larger prey (McCormick and Polis 1982). Conversely, the diet of anurans generally includes small spiders. Therefore, in some cases, the interaction between these taxa may represent intraguild predation (McCormick and Polis 1982, Rubbo et al. 2003). As spiders can reach high densities on the forest floor, especially species 
of the genera Ctenus and Ancylometes (Gasnier 1996), this interaction may be ecologically important for breeding anurans. This study provides evidence that spiders commonly prey on amphibians, but the impact of predation on populations of amphibians remains unknown.

\section{Acknowledgements}

We thank A. P. Lima, W. E. Magnusson, W. Hödl, D. M. M. Oliveira, J. Zuanon and V. F. V. Pazin for communicating their observations on spiders eating frogs; W. E. Magnusson, A. P. Lima, T. Gasnier and two anonymous reviewers for critical suggestions on the manuscript; $M$. Davis for the English review; A. P. Lima, W. E. Magnusson and W. Hödl for photos; J. S. Lopes and J. T. Nascimento for field work assistance; IBAMA for collect permission of frogs (\# 036/03 and 099/04); CNPq / PNOPG (\# 471453/03-0, 550651/01-2) for financial support. This work was supported by graduate fellowships from CNPq to DJR, and CAPES to MM and CSA.

\section{References}

Aucone, B. and W. Card. 2002. Scinax cruentomma (NCN). Predation. Herpetological Review 33: 48.

Azevedo, C. S. and M. Smith. 2004. Araneofauna na região do Seringalzinho. Pp. 135-142 in S. H. Borges, S. Iwanaga, C. C. Durigan and M. R. Pinheiro (eds.), Janelas para a Biodiversidade no Parque Nacional do Jaú: uma estratégia para o estudo da biodiversidade na Amazônia. Manaus. Fundação Vitória Amazônia.

Bastos, R. P., O. C. Oliveira and J. P. Pombal Jr. 1994. Hyla minuta (NCN). Predation. Herpetological Review 25: 118.

Bauer, A. M. 1990. Gekkonid lizards as prey of invertebrates and predators of vertebrates. Herpetological Review 21: 83-87.

Bernarde, P. S., M. B. Souza and M. N. C. Kokubum. 1999. Predation on Hyla minuta Peters, 1872 (Anura, Hylidae) by Ancylometes spp. (Araneae, Pisauridae). Biociências 7: 199-203.

Blackburn, L. M., C. D. Hoefler and P. Nanjappa. 2002. Acris crepitans blanchardi (Blanchard's Cricket Frog). Predation. Herpetological Review 33: 299.
Boistel, R. and O. S. G. Pauwels. 2002a. Oscaecilia zweifeli (Zweifel's caecilian). Predation. Herpetological Review 33: 120-121.

Boistel, R. and O. S. G. Pauwels. 2002b. Leptodactylus knudseni (Knudsen's bullfrog). Predation. Herpetological Review 33: 303.

Cangialosi, K. R. 1990. Life cycle and behavior of the kleptoparasitic spider, Argyrodes ululans (Araneae, Theridiidae). Journal of Arachnology 18: 347-358.

Del-Grande, M. L. and G. Moura. 1997. Hyla sanborni (NCN). Predation. Herpetological Review 28: 147.

Duellman, W. E. and L. Trueb. 1994. Biology of Amphibians. Baltimore and London. The Johns Hopkins University Press. 670 pp.

Formanowicz Jr., D. R., M. M. Stewart, K. Towsend, F. H. Pough, and P. F. Brussard. 1981. Predation by giant spiders on the Puerto Rican frog Eleutherodactylus coqui. Herpetologica 37: 125-129.

Gasnier, T. R. J. 1996. Ecologia comparada de quatro espécies de aranhas errantes do gênero Ctenus (Walckenaer) (Araneae, Ctenidae) em uma floresta na Amazônia Central: bases para um modelo integrado de coexistência. Unpublished Ph. D. Thesis. Instituto Nacional de Pesquisas da Amazônia, Brazil.

Gasnier, T. R. and H. Höfer. 2001. Patterns of abundance of four species of wandering spiders (Ctenidae, Ctenus) in a forest in central Amazonia. Journal of Arachnology 29: 95-103.

Giaretta, A. A. and M. Menin. 2004. Reproduction, phenology and mortality sources of a species of Physalaemus (Anura: Leptodactylidae). Journal of Natural History 38: 1711-1722.

Goin, C. J. 1943. The lower vertebrate fauna of the water hyacinth community in Northern Florida. Proceedings of Florida Academy of Sciences 6: 143-153.

Gray, H., D. M. Green and M. J. Peters. 1999. Physalaemus pustulosus (Túngara Frog). Predation. Herpetological Review 30: 93.

Hayes, M. P. 1983. Predation on the adults and prehatching stages of glass frog (Centrolenidae). Biotropica 15: 74-76.

Heyer, W. R., R. W. McDiarmid and D. L. Weigmann. 1975. Tadpoles, predation and pond habitats in the tropics. Biotropica 7: 100-111.

Hinshaw, S. H. and B. K. Sullivan. 1990. Predation on Hyla versicolor and Pseudacris crucifer during reproduction. Journal of Herpetology 24: 196-197.

Höfer, H. and A. D. Brescovit. 2000. A revision of the Neotropical spider genus Ancylometes Bertkau (Araneae: Pisauridae). Insect Systematics \& Evolution 31: 323-360.

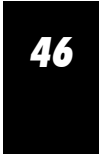


Höfer, H., A. D. Brescovit and T. Gasnier. 1994. The wandering spiders of the genus Ctenus (Ctenidae, Araneae) of Reserva Ducke, a rainforest reserve in central Amazonia. Andrias 13: 81-98.

Lutz, B. 1973. Brazilian Species of Hyla. Austin and London. University of Texas Press. 265 pp.

Marra, R. V., F. H. Hatano, L. Boquimpani-Freitas, R. V. Marques, M. Van Sluys, and C. F. D. Rocha. 2003. Scinax altera (NCN). Predation. Herpetological Review 34: 55-56.

McCormick, S. and G. A. Polis. 1982. Arthropods that prey on vertebrates. Biological Review of Cambridge Philosophical Society 57: 29-58.

Menin, M. and A. A. Giaretta. 2003. Predation on foam nests of leptodactyline frogs (Anura: Leptodactylidae) by larvae of Beckeriella niger (Diptera: Ephydridae). Journal of Zoology 261: 239-243.

Mitchell, J. C. 1990. Pseudacris feriarum (Upland Chorus Frog). Predation. Herpetological Review 21: 89-90.

Nyffeler, M., H. Moor and R. F. Foelix. 2001. Spiders feeding on earthworms. Journal of Arachnology 29: $119-124$.

Owen, R. D. and S. A. Johnson. 1997. Pseudacris ocularis (Little Glass Frog). Predation. Herpetological Review 28: 200.

Prado, G. M. and J. H. Borgo. 2003. Scinax altera (NCN). Predation. Herpetological Review 34: 238239.

Pramuk, J. B. and H. Alamillo. 2002. Hyla nana (Dwarf Tree Frog). Predation. Herpetological Review 33: 46-47.

Raven, R. J. 1990. Spider predators of reptiles and amphibian. Memoirs of the Queensland Museum 29: 448.

Rubbo, M. J., V. R. Towsend Jr, S. D. Smyers, and R. G. Jaeger. 2003. An experimental assessment of invertebrate/vertebrate predation: the interaction between wolf spider (Gladicosa pulchra) and terrestrial salamanders (Ambystoma maculatum). Journal of Zoology 261: 1-5.

Sandidge, J. S. 2003. Scavenging by brown recluse spiders. Nature 426: 30.

Schiesari, L. C., F. A. Juncá and G. M. Accacio. 1995. Hylodes phyllodes (NCN). Predation. Herpetological Review 26: 30-31.

Summers, K. 1999. Dendrobates auratus (Green Poison Frog). Predation. Herpetological Review 30: 91.

Szelistowski, W. A. 1985. Unpalatability of the poison arrow frog Dendrobates pumilio to the ctenid spider Cupiennius coccineus. Biotropica 17: 345346.

Toledo, L. F. 2003. Predation on seven South American anuran species by water bugs (Belostomatidae). Phyllomedusa 2: 105-108.

Villa, J., R. W. McDiarmid and J. M. Gallardo. 1982. Arthropod predators of leptodactylid frog foam nests. Brenesia 19/20: 577-589.

Villanueva-Rivera, L. J., R. L. Joglar and F. C. Li-Objio. 2000. Eleutherodactylus coqui (Coqui). Predation. Herpetological Review 31: 100.

Wise, D. H. 1993. Spiders in Ecological Webs. Cambridge. Cambridge University Press. 328 pp.

Zar, J. H. 1999. Biostatistical Analysis. New Jersey. Prentice-Hall. 663 pp. 